\title{
Resistir era preciso: O Decreto de Emancipação de 1978, os povos indígenas e a sociedade civil no Brasil
}

Poliene Bicalho ${ }^{1 ; *}$

1Universidade Estadual de Goiás, Anápolis, Goiás, Brasil

\section{RESUMO}

O Decreto de Emancipação de 1978 e a atuação da sociedade civil organizada, permeados pelo emergente protagonismo indígena, compóem o objeto central de reflexão deste artigo. O empoderamento da oposição às forças políticas autoritárias, que desejavam impor o referido decreto, é o que sustenta a hipótese de que a cena histórica e política que se formou em torno deste projeto de emancipação forçada dos indígenas representa o segundo acontecimento fundador do Movimento Indígena no Brasil. Uma das considerações a que se chegou foi a de que o ato de emancipar o índio seria um grande erro do Estado em relação às diversas etnias indígenas do país. A principal fonte histórica utilizada na composição desta discussão, entre outras, foi a publicação da Comissão Pró-Índio de São Paulo, de 1979, Histórico da Emancipação, além de alguns dossiês encontrados no Arquivo Nacional.

Palavras-chave: Decreto de Emancipação de 1978; Protagonismo Indígena; Sociedade Civil; Movimento indígena; Estado.

\section{Resisting was necessary: the 1978 Emancipation Decree, indigenous peoples and civil society in Brazil}

\section{ABSTRACT}

This article's main aim is to further academic understanding of the 1978 Emancipation Decree and of the actions of organized civil society, which were permeated by emerging Indigenous protagonism. Increasing opposition empowerment against authoritarian political forces, who wished to impose the referred decree, is what sustains the idea that the historical and political scene concerning this project of forced indigenous emancipation represents the second founding event of the Indigenous Movement in Brazil. One of the conclusions was that the act of emancipating Indigenous people could be recognized as a notorious state mistake towards di-

DOI: http://dx.doi.org/10.1590/2237-101X02004007

Artigo recebido em 12 de julho de 2017 e aceito para publicaçáo em 23 de fevereiro de 2018.

* Professora da Universidade Estadual de Goiás/Departamento de História, Anápolis/GO — Brasil. E-mail: poliene.soares@gmail.com. https://orcid.org/0000-0002-8324-8743. 
verse ethnic groups of the country. The main historical sources used in the article were, among others, a 1979 publication entitled Histórico da Emancipação (Emancipation History), issued by the organization called Comissão Pró-Índio de São Paulo (Pro-Indian Commission of Sao Paulo), as well as several dossiers found in the Arquivo Nacional (National Archive).

Keywords: The 1978 Emancipation Decree; Indigenous Protagonism; Civil Society; Indigenous Movement; State.

\section{Resistir era necesario: El Decreto de Emancipación de 1978, los pueblos indígenas y la sociedad civil en Brasil}

\section{RESUMEN}

El Decreto de Emancipación de 1978 y la actuación de la sociedad civil organizada, permeados por el emergente protagonismo indígena, componen el objeto central de reflexión de este artículo. El empoderamiento de la oposición a las fuerzas políticas autoritarias, que deseaban imponer el referido Decreto, es lo que sustenta la hipótesis de que la escena histórica y política que se formó en torno de ese proyecto de emancipación forzada de los indígenas representa el segundo acontecimiento fundador del Movimiento Indígena en Brasil. Una de las consideraciones a la que se llegó fue la de que el acto de emancipar el indio sería un grande error del Estado en relación a las diversas etnias indígenas del país. La principal fuente histórica utilizada en la composición de esta discusión, entre otras, fue la publicación de la Comisión Pro-Indio de São Paulo de 1979, Histórico de la Emancipación, además de algunos Dossier encontrados en el Archivo Nacional.

Palabras clave: Decreto de Emancipación de 1978; Protagonismo Indígena; Sociedad Civil; Movimiento Indígena; Estado.

O Índio: Ame-o ou emancipe-o Henfil $^{1}$

O processo histórico de surgimento, estruturação e organização do Movimento Indígena no Brasil foi marcado por cinco acontecimentos que delinearam o protagonismo indígena na luta por direitos específicos no Brasil: as Assembleias Indígenas; o Decreto de Emancipação de 1978; a Assembleia Nacional Constituinte de 1987/Constituição de 1988; as Comemoraçóes dos 500 anos do Brasil; e o Abril Indígena/Acampamento Terra Livre, já no século XXI.

\footnotetext{
${ }^{1}$ Charge de HENFIL. In: HISTÓRICO DA EMANCIPAÇÃO, São Paulo, 1979. Comissão Pró-Índio/SP. 1. ed. São Paulo: Parma, 1979, p. 1-92.
} 
Neste trabalho, dentre esses diferentes marcos, propóe-se uma reflexão sobre o Decreto de Emancipação de 1978, compreendido aqui, a partir da análise de Paul Ricouer, ${ }^{2}$ como um acontecimento fundador, ${ }^{3}$ na medida em que possibilitou renovar as tradiçóes e propiciar a continuidade histórica do Movimento Indígena, bem como evidenciar o protagonismo de lideranças e organizaçóes no que tange aos interesses e direitos indígenas no contexto da luta social e étnica do final da década de 1970 no Brasil.

O protagonismo indígena começa a despontar efetivamente, sob a perspectiva de um movimento social de caráter étnico, com o surgimento das Assembleias Indígenas, que não serão aprofundadas neste artigo. Trata-se de inúmeros encontros que reuniram várias etnias indígenas, ocorridos no Brasil a partir de 1974, incialmente idealizados pelo Conselho Indigenista Missionário (Cimi), mas com a participação direta das lideranças indígenas no processo de organização e dinamização das demandas internas necessárias à realização desses encontros.

A proposta do Cimi era tornar as Assembleias cada vez mais autônomas, com a mínima participação de não indígenas, para que, assim, os indígenas se sentissem mais à vontade para exporem suas demandas, angústias, necessidades e anseios entre os "parentes" de diferentes etnias do país. Segundo João Pacheco de Oliveira Filho, as "assembleias indígenas funcionavam como foros políticos abertos, sem estrutura burocrática nem forma de ação contínua". ${ }^{4}$

O Movimento Indígena no Brasil se iniciou de maneira organizada a partir dessas Assembleias Indígenas, como resultado do Movimento Pan-Indígena, criado e consolidado entre os anos 1970 e 1984, segundo Maria Helena Ortolan Matos. Entre 1974 e 1980, "quinze dessas assembleias tiveram lugar em diferentes partes do país", ${ }^{6}$ realizando um trabalho de mobilização das bases por meio das lideranças indígenas de várias etnias em diversos lugares, evidenciando, assim, a emergência de um protagonismo indígena no que tange à luta por seus direitos.

Em meados dos anos 1970 algumas lideranças indígenas no Brasil começaram a sair de suas comunidades rumo aos grandes centros, em busca de apoio para a causa indígena, e expuseram à comunidade nacional uma realidade pouco conhecida, ou mesmo ignorada. Esses acontecimentos tiveram lugar durante os anos do entáo milagre econômico do governo do general Emílio Garrastazu Médici (1969-1974); e, em seguida, ocorreu a tentativa de

\footnotetext{
${ }^{2}$ RICOEUR, Paul. O conflito das interpretaçôes. Ensaios de hermenêutica. Tradução de M. F. Sá Correia. Porto: Rés Editora, 1989.

${ }^{3}$ Acontecimento Fundador: Termo/conceito cunhado por Paul Ricoeur que, entre outros aspectos, caracteriza-se pela ruptura e desestabilização das estruturas, trazendo à tona a "dupla historicidade da tradição que transmite e sedimenta a interpretação, e da interpretação que mantém e renova a tradição". Ibidem, p. 49.

${ }^{4}$ OLIVEIRA FILHO, João Pacheco de. O nascimento do Brasil e outros ensaios. "Pacificação", regime tutelar e formação de alteridade. Rio de Janeiro: Contra Capa, 2016, p. 277.

5 MATOS, Maria Helena Ortolan. Rumos do movimento indígena no Brasil contemporâneo: experiências exemplares no Vale do Javari. 2006. 274 f. Tese (Doutorado) — Departamento de Antropologia do Instituto de Filosofia e Ciências Humanas da Universidade de Campinas, Unicamp, Sáo Paulo, 2006, p. 1.

${ }^{6}$ CARDOSO DE OLIVEIRA, Roberto. A crise do indigenismo. Campinas: Editora Unicamp, 1988, p. 20.
} 
imposição do Decreto de Emancipação de 1978, durante o governo do general Ernesto Geisel (1974-1978), com importante atuação da sociedade civil e de lideranças e comunidades indígenas como forças de oposição ao referido decreto.

Por condensar uma série de debates e tratar da participação de indígenas nos marcadores de identidade e diferença (direitos específicos), neste artigo, adota-se a concepção de protagonismo dos atores e autores que, nas últimas décadas, atuam, analisam e discutem os movimentos sociais. Contudo, é importante destacar que, como é de conhecimento, protagonizar significa, principalmente, o ato ou o fato de se tornar o ator mais importante de algum evento. Conforme a etimologia do termo protagonismo, este surgiu na Grécia Antiga e, segundo Darci Secchi, originou-se da palavra protagonista: "composta pelas raízes das palavras proto, que se traduz como 'o principal', e agonistes, que significa 'lutador."'

Entretanto, conforme destaca Maria da Glória Gohn, o termo é permeado por inconstâncias históricas inerentes aos seus sentidos e significados. Pois, na própria Grécia, protagonista poderia ser o "lutador principal de um torneio", 8 ou ainda os atores principais de obras literárias ou tramas teatrais. Nas ciências humanas o termo passou a ser utilizado no período em que as organizaçóes e os movimentos da sociedade civil foram adquirindo autonomia, sendo assim, os sujeitos invisibilizados passaram a assumir o caráter de protagonistas de suas lutas e histórias.

Nessa perspectiva, conforme observa Gohn, nas ciências humanas, as palavras ator e protagonista passaram a referir-se aos "atores que configuram as açóes de um movimento social" a partir da atitude do movimento intelectual, amparado em abordagens histórico-sociológicas, repensando e evidenciando a importância de sujeitos históricos ignorados pela historiografia tradicional. Tal significado passou a ser utilizado também para fazer referência aos atores sociais e políticos de diversos setores da sociedade civil — movimentos sociais, Organizações Não Governamentais (ONGs), instituições oficiais, entre outros — que surgiram com o intuito de lutar por setores marginalizados devido às suas condiçóes econômica, social, cultural e étnica.

Sobre os movimentos sociais, especificamente, de acordo com Gohn, trata-se de "açóes sociais coletivas de caráter sociopolítico e cultural que viabilizam distintas formas de a população se organizar e expressar suas demandas". ${ }^{10}$ Alain Touraine, ${ }^{11}$ entretanto, foi mais criterioso ao elaborar sua explicação teórica e ao demonstrar as características gerais dos movimentos sociais. Para o autor, ao sugerir uma análise mais abrangente sobre o

\footnotetext{
7 SECCHI, Darci. Autonomia e protagonismo indígena nas políticas públicas. In: JANUÁRIO, Elias; SELLERI, Fernando Silva; KARIN, Taisir Mahmudo (Org.). Cadernos de Educação Escolar Indígena Proesi. Barra do Bugres: Ed. Unemat - Universidade do Estado do Mato Grosso, v. 5, n. 1, p. 11-20, 2007. ${ }^{8} \mathrm{GOHN}$, Maria da Glória. O protagonismo da sociedade civil: movimentos sociais, ONGs e redes solidárias. 2. ed. São Paulo: Cortez, 2008, p. 9.

${ }^{9}$ Idem.

${ }^{10}$ GOHN, Maria da Glória (Org.). Movimentos sociais no início do século XXI: antigos e novos atores sociais. Petrópolis: Vozes, 2003, p. 13.

${ }^{11}$ TOURAINE, Alain. Palavra e sangue: política e sociedade na América Latina. São Paulo: Editora Unicamp, 1989, p. 181-182.
} 
conceito, é necessário antes considerar que a noção de movimentos sociais apresenta três sentidos principais:

Para alguns, movimento social é a defesa nacional de interesses coletivos [...]. Para outros, os movimentos sociais seriam reaçóes à comoção de um dos principais aspectos do sistema social, quando as instituições políticas não têm capacidade para realizar os ajustes necessários... É necessário, pois, adotar o terceiro sentido dado à noçáo de movimento social: um conflito social que opóe formas sociais contrárias de utilização dos recursos e dos valores culturais, sejam estes de ordem do conhecimento, da economia ou da ética. ${ }^{12}$

No Brasil, a partir dos anos 1970 e, principalmente, na primeira década do século XXI, as relaçóes sociais e políticas entre Estado e sociedade foram marcadas pela atuação de diferentes atores/ protagonistas. Ao analisar a relação deste contexto com a força que ganhou a noção de protagonismo da sociedade civil, Adrián Gurza Lavalle, Graziela Castello e Renata Mirandola Bichir apresentam uma tipologia desses atores classificados em sete grupos: "ONGs, organizaçóes populares, associaçōes de bairro, associações comunitárias, entidades assistenciais, articuladoras e fóruns."13

A partir dessa acepção, os movimentos sociais são classificados na categoria das organizaçóes populares. Essas, no Brasil, ganharam notoriedade na segunda metade do século XX, ao se oporem e manterem relaçóes de resistência ao Estado cerceador de direitos sociais e políticos. E, após a ditadura militar, as mobilizaçóes sociais mudaram o foco, transferindo o campo de atuação das ruas para os ambientes institucionalizados.

Neste ínterim, em crise, os movimentos populares se rearticularam, interna e externamente, proporcionando à cena política a atuação direta dos novos atores sociais. Assim, uma nova cultura política pública, contrária às práticas autoritárias, clientelistas e corporativas vigentes, começou a se desenvolver no país. Ela pode ser definida por "processos nos quais os diferentes interesses são reconhecidos, representados e negociados, via mediaçóes sociopolíticas e culturais" ${ }^{14}$, e mediada pela pauta dos direitos sociais, étnicos, culturais, políticos e econômicos.

O protagonismo dos movimentos sociais no Brasil, no início dos anos 1990, passou por um processo de recrudescimento em razão dos novos rumos sinalizados pela conquista de direitos constitucionais em 1988, que precisavam ser regulamentados num contexto de redemocratização política e implementação de políticas econômicas neoliberais, como observa Gohn. ${ }^{15}$ As formas de mobilização e as lutas sociais que ocorreram no período da ditadura

\footnotetext{
${ }^{12}$ Idem.

${ }^{13}$ LAVALLE, Adrián Gurza; CASTELLO, Graziela; BICHIR, Renata Mirandola. Os bastidores da sociedade civil - Protagonismos, redes e afinidades no seio das organizaçóes civis. Centro Brasileiro de Análise e Planejamento. São Paulo: Cebrap, p. 1-79, nov. 2006.

${ }^{14}$ GOHN, Maria da Glória. Empoderamento e participação da comunidade em políticas sociais. Saúde e Sociedade, São Paulo, v. 13, n. 2, p. 20-31, maio/ago. 2004.

${ }^{15}$ GOHN, Maria da Glória. O protagonismo da sociedade civil: movimentos sociais, ONGs e redes solidárias,
} 
ficaram ultrapassadas. Nesse sentido, do ponto de vista geográfico, os movimentos populares nos campos se fortaleceram e os movimentos populares urbanos perderam força.

Apesar disso, a denominada crise dos movimentos sociais urbanos da década de 1990 é questionável, pois eles passaram por uma fase de rearticulação, com o intuito de reposicionar as novas demandas sociais diante das mudanças no mercado de trabalho e das "novas políticas públicas"16 inerentes à conjuntura política global. Sob essa circunstância, passaram a atuar em redes, ampliaram espaços de luta e participação e se destacaram pela atuação mais direta de atores sociais participantes nos movimentos, ou seja, assumiram o papel de protagonistas de suas próprias histórias.

Assim, os novos movimentos sociais, ou movimentos sociais contemporâneos, a partir da segunda metade da década de 1990 focaram suas açôes nas questóes étnicas, de gênero e outros, e se caracterizam por serem mais propositivos do que reivindicativos. ${ }^{17}$ Nos anos 1990 e, mais precisamente, na primeira década do século XXI, as relaçôes entre a sociedade civil - especialmente quanto ao movimento indígena, às ONGs e às organizaçóes indígenas - e o Estado se modificaram significativamente. As organizaçóes indígenas proliferaram e sofreram mudanças substanciais no tocante às suas origens e práticas de atuação. Sobre esse aspecto, Oliveira Filho ressalta:

O contexto modificou-se radicalmente a partir de 1991. Preocupados com o fato de o Brasil ser o país sede de Segunda Conferência Mundial sobre Meio Ambiente e Desenvolvimento das Nações Unidas (Eco-92) os organismos governamentais aceleraram o processo de demarcaçáo de terras indígenas [...]. Tomando o ano de 1992 e a ECO-92 como marcos, as formas de atuaçáo, os temas e a retórica das ONGS mudaram com velocidade bem maior. A preocupação básica com direitos humanos e a implementação da democracia, que nortearam a atuação das ONGS nos anos 1970 e 1980, deixaram de ser uma prioridade, com a atenção deslocando-se para os debates sobre uso e conservação de recursos naturais. O quadro de pessoal das ONGS passou a ter um perfil muito mais técnico e profissionalizado - as figuras de voluntários e militares tornaram-se raras. A postura crítica e de radical autonomia, que predominava nas décadas anteriores, foi substituída por uma interlocução permanente com os órgãos de governo e com a cooperação internacional. [...] O terceiro ponto a se considerar é a despolitização das ações engendradas pelas ONGS e organizaçôes indígenas, que passam a adotar uma linguagem meramente técnica e a operar com metas e meios de ação julgados sempre como consensuais [...]..$^{18}$

Nesse processo de redefinição de foco dos movimentos sociais e de uma nova concepção de políticas públicas, os indígenas deixaram de ser apenas mais um dos alvos de inciativas do Estado e se tornaram mais atuantes em prol da conquista e da permanência de direitos. Por consequência, os sujeitos historicamente silenciados passaram a ser atores, agentes, elaboradores, incentivadores,

op. cit., p. 79.

${ }^{16}$ Ibidem, p. 81.

${ }^{17}$ GOHN, Maria da Glória. Empoderamento e participação da comunidade em políticas sociais, op. cit.

${ }^{18}$ OLIVEIRA FILHO, João Pacheco de. O nascimento do Brasil e outros ensaios. "Pacificaçáa", regime tutelar e formação de alteridade, op. cit., p. 280-283. 
criadores, participantes e proponentes, com direito de voz e, em algumas situaçóes, de voto, nas decisões outrora tomadas pelo Estado e que os atingiam diretamente, ainda que, muitas vezes, subsidiados por organizaçôes indígenas e/ou ONGs, estas nem sempre efetivamente comprometidas com as causas originárias e essenciais da luta indígena, uma vez que atuavam "mais na condição de parceiros que fornecem uma assessoria técnica”, ${ }^{19}$ principalmente após os anos 1990.

Com a presença mais direta e dinâmica de lideranças e organizaçóes indígenas, Cardoso de Oliveira destaca que o "movimento indígena se encarregou de dar ao índio o autorrespeito que faltava”. ${ }^{20}$ Nesse sentido, os indígenas assumiram, nas últimas décadas, um protagonismo sociopolítico típico dessa tomada de consciência que caracteriza a luta social e evidencia a resistência coletiva como expressividade dos movimentos sociais. Desse modo, se conformou no Brasil um protagonismo indígena caracterizado pela atuação e pela consciência da necessidade da luta social para fins de reconhecimento dos direitos específicos dos povos, na perspectiva da legalidade e da legitimidade. Sendo assim, a noção de protagonismo indígena no Brasil, portanto, não se afasta do significado inicial da palavra protagonista, e a luta dos indígenas por seus direitos insere-se no que se compreende como movimento social, a partir de uma conformaçáo que envolvia lideranças e organizaçóes indígenas, ONGs e outras associaçóes típicas da sociedade civil organizada.

Na década de 1970 ocorreu uma gradual organização do movimento social indígena, o que propiciou o início do processo de sistematização da consciência de luta, ou seja, estava se formando naquele período o que atualmente denomina-se de protagonismo indígena. Resistir às diversas iniciativas colonizadoras impostas há mais de quinhentos anos de história, tais como escravidáo, evangelização, imposição de outras culturas, integração, assimilação, entre outras, era realmente preciso e necessário.

\section{O Decreto de Emancipação de 1978, o protagonismo indígena e a sociedade civil no Brasil}

A história do projeto de emancipaçáo dos índios almejado pelo governo militar — materializada no Decreto de Emancipação de 1978, que visava regulamentar os artigos 9o․ 10, 11, 27 e 29 da Lei no 6.001 de 19 de dezembro de 1973 - é mais um importante momento definidor do processo de formação e organização do Movimento Indígena no Brasil. Nota-se, durante os debates que perpassaram a ação daqueles que faziam oposição ao decreto, uma nítida ascensão do grau de conscientização étnica por parte dos indígenas e uma significativa atuaçáo da sociedade civil contra mais um ato autoritário e pernicioso do governo ditatorial.

Acredita-se, como hipótese central deste artigo, que esse momento representa o segundo acontecimento fundador do Movimento Indígena no país, e, como tal, simboliza um perío-

\footnotetext{
${ }^{19}$ Ibidem, p. 281.

${ }^{20}$ OLIVEIRA, Roberto Cardoso de. Caminhos da identidade: Ensaios sobre etnicidade e multiculturalismo. 1. ed. São Paulo: Ed. Unesp; Brasília: Paralelo 15, 2006, p. 53.
} 
do de atualização permanente de suas tradiçôes. Como se espera e se imagina, um acontecimento fundador - além de causar a ruptura num período de longa duraçáo e proporcionar o conhecimento - precisa ser também constantemente atualizado, de modo que faça uso da "diferença, da excepcionalidade que cria, mas, para se constituir como tal, é preciso ainda que uma ampla maioria de pessoas tome conhecimento de sua existência". ${ }^{21}$

Muito provavelmente, antes da formação da Assembleia Nacional Constituinte em 1987, a ampla mobilização da sociedade civil — representada basicamente por organizaçôes indígenas como a Comissão Pró-Índio de São Paulo (CPI/SP), a Associação Brasileira de Antropologia (ABA) e a Igreja Católica, representada pelo Conselho Indigenista Missionário (Cimi), entre tantas outras - nas principais cidades do país, contrárias ao decreto, representou o momento em que o Movimento Indígena tornou-se conhecido em todo o Brasil.

A proposta de emancipaçáo dos índios escandalizou setores e personalidades importantes da intelectualidade atuante, da Igreja e da imprensa brasileira, que já vinham formando frentes de oposição ao regime por meio da ampla atuação da sociedade civil organizada. Para o Movimento Indígena, ainda em formação, o instante foi de grande emergência nacional, pois,

entre os anos de 1978 e 1980, as lutas contra os projetos do regime militar de emancipação compulsória dos índios, e de definiçâo de "critérios de identidade étnica" acabaram representando um marco histórico no processo de articulação entre o recém-formado movimento indígena, e as forças progressistas de apoio à causa indígena. ${ }^{22}$

As principais fontes primárias utilizadas para compor a análise desse acontecimento fundador do Movimento Indígena no Brasil estão disponíveis numa publicação da Comissão Pró-Índio de São Paulo intitulada Histórico da emancipação, de 1979. Em janeiro de 1975 o Ministro do Interior, Rangel Reis, anunciou à imprensa a possibilidade de alteraçáo do Estatuto do Índio no que dizia respeito à emancipação das comunidades indígenas. Começou, então, a se organizar e a se impor uma ampla frente de oposição ao anunciado desejo do governo. A meta do ministro, em consonância com as diretrizes do governo Geisel, era “...acabar com o paternalismo da Funai e adotar uma política agressiva de integração (sic) através da implantação de projetos de desenvolvimento econômico de áreas indígenas". ${ }^{23}$

Os projetos desenvolvimentistas dos governos ditatoriais desse período convergiram diretamente para as terras indígenas, tornando esses povos mais vulneráveis à política integracionista do Estado. Neste contexto, as reuniōes de diferentes grupos indígenas de todas as regióes do Brasil, as Assembleias Indígenas, tornaram conhecidas as dificuldades enfren-

\footnotetext{
${ }^{21}$ BARBOSA, Marialva. A narrativa, a experiência e o acontecimento de novos regimes de visibilidade da TV brasileira. Tempo, Rio de Janeiro, n. 17, p. 153-172, 2004.

${ }^{22}$ LACERDA, Rosane Freire. Os povos indígenas e a Constituinte - 1987/1988. Brasília: Conselho Indigenista Missionário (Cimi), 2008, p. 30.

${ }^{23}$ HISTÓRICO DA EMANCIPAÇÃO, op. cit., p. 10.
} 


\section{Poliene Bicalho}

tadas e demonstraram a necessidade de novas formas de relacionamento entre o Estado, a sociedade e os povos indígenas.

Estes, como a maioria da população, compunham o grupo dos excluídos da distribuição da renda do país; porém, mais que isso, foram atingidos diretamente pelos grandes projetos de integração nacional postos em execução pelo governo na época, como a Transamazônica, por exemplo, que foi inaugurada "em meio a críticas pela devastação do ambiente e pela invasão de terras indígenas". ${ }^{24}$ Esta obra, BR-230, um dos projetos faraônicos da administração dos militares (general Emílio Garrastazu Médici, 1969-1974) — entre tantos outros grandes projetos, ${ }^{25}$ e que atingiu diretamente alguns povos indígenas da Amazônia, muitos ainda sem nenhum ou pouco contato com a sociedade nacional — foi inaugurada antes de ser concluída em 1972, como parte do plano que almejava integrar e controlar o território nacional a todo custo, ${ }^{26}$ mesmo que para isso centenas de povos fossem sacrificados. ${ }^{27}$

Nessa perspectiva é que se explicava a necessidade do projeto de emancipação, cujo objetivo maior era liberar as terras indígenas para a implantação desses projetos desenvolvimentistas. Contudo, a ocupação permanente dos territórios indígenas gerou um quadro de mobilizaçóes que começou a ganhar expressividade no país, principalmente nos setores urbanos mais desenvolvidos, contando com o apoio de diversos setores da sociedade civil.

As críticas ao anunciado pelo ministro partiram de vários cantos do país. Antropólogos do Museu Göeldi, em Belém, já em 1975 declararam que a integração dos índios à sociedade nacional sempre acontecia em um nível inferior ao da vida comunitária. Em 1976, enquanto

\footnotetext{
${ }^{24}$ FAUSTO, Boris. História do Brasil. 8. ed. São Paulo: Edusp, 2000, p. 574.

${ }^{25}$ Projeto Carajás, Projeto Polonoroeste, Projeto Calha Norte etc. Em relação às estradas, que na década de 1970 representavam uma das principais metas do Plano de Integração Nacional (PIN), várias foram as rodovias federais que atravessaram terras indígenas, deixando para trás centenas de mortes e uma série de doenças: BR-163 (Cuiabá-Santarém)/Território dos Paraná ou Kren-Akrôto (MT/PA); BR-174 (Manaus-Caracaraí)/ Território dos Waimiri-Atroari (AM); BR-210 (Perimetral Norte)/Território dos Yanomami; BR-230 (Transamazônica)/Território dos "Parintitin (AM), Pirahã (AM), Tenharim (AM), Munduruku (PA), Arara (PA), Assurini (PA), Juruna (PA), Kararahô (PA), Parakanã (PA) e Apinajé (TO)”. Muitas foram as remoçóes dos índios de suas terras nesse período em consequência das invasóes dos territórios indígenas não somente pelas estradas como também pelo garimpo, a mineração, a construção de barragens e usinas hidroelétricas, entre outras iniciativas da ânsia desenvolvimentista daqueles anos de ditadura. In: LACERDA, Rosane. Os povos indígenas e a Constituinte - 1987/1988, op. cit., p. 19-20.

${ }^{26}$ RIBEIRO, Gustavo Lins. Militares, Antropologia, Desenvolvimento. In: OLIVEIRA FILHO, João Pacheco (Org.). Projeto Calha Norte. Militares, índios e fronteiras: Antropologia e indigenismo, 1. Rio de Janeiro: Peti/Ed. UFRJ, 1990, p. 89.

27 "A Transamazônica foi a grande obra inconclusa do período mais autoritário do Brasil. Foi apresentada como a integradora da nação, que iria juntar os pontos mais remotos do país ao seu centro propulsor. Sem ter cumprido essas metas, ela, no entanto, causou diversos desastres no que concerne às populaçóes indígenas. Em primeiro lugar, pelo simples fato de ser aberta em áreas indígenas, surgiu a necessidade imediata de se contatar povos indígenas, como o Parakanã e Assurini e, em alguns casos, fazer transferências de grupos e aldeias para outras áreas. Nesse processo, muitos índios morriam em pouco tempo após o contato e posteriormente nas suas novas áreas...” In: GOMES, Mércio Pereira. Os índios e o Brasil. Ensaio sobre um holocausto e sobre uma nova possibilidade de convivência. Petrópolis: Vozes, 1988, p. 177.
} 
o ministro Rangel Reis declarava que o objetivo da política indigenista era emancipar algumas comunidades indígenas e que a época certa para a realização dessa emancipação seria determinada pela Funai, o sertanista Orlando Villas-Boas falava à imprensa, por intermédio do jornal O Estado de São Paulo, criticando a iniciativa do governo. ${ }^{28}$

Em 1977 o Museu Nacional do Rio de Janeiro divulgou um manifesto contrário à proposta de emancipação assinado por dezessete antropólogos. Também os indígenas da etnia Gaviáo se manifestaram enviando do Pará uma mensagem gravada em fita magnética ao presidente da Funai, general Ismarth de Araújo, na qual "diziam que a emancipação definitiva da tribo é prematura". ${ }^{29}$ Afinal, as condiçōes de vida e o reconhecimento dos direitos específicos desses povos ainda eram precários, como se observa no texto subsequente a esta mensagem dos Gavião, nesta mesma publicação da Comissão Pró-Índio de São Paulo, durante a realização da $1^{\text {a }}$ Assembleia Nacional dos Índios Brasileiros, realizada em Santo Ângelo (RS), quando 26 caciques de nove etnias enviaram um documento ao presidente da Funai no qual solicitavam melhorias para as suas péssimas condiçōes de vida.

Em 1978 intensificaram-se as manifestaçóes contrárias à iniciativa do governo, e, mesmo diante de protestos, o ministro Rangel Reis afirmou que o Decreto de Emancipação seria assinado pelo presidente Ernesto Geisel ainda em fevereiro daquele ano, e que a "medida 'beneficiaria' 2 mil índios, emancipando 100 no atual governo". ${ }^{30}$ Para o líder Xavante Mário Juruna, primeiro e único deputado indígena eleito no Brasil, em 1982, a emancipação levaria ao desaparecimento dos indígenas, que se tornariam simples caboclos. ${ }^{31}$

Entre as representantes da sociedade civil organizada, as várias regionais do Conselho Indigenista Missionário (Cimi) no país manifestaram-se contrárias ao decreto, juntamente com a Associação Nacional de Apoio ao Índio (Anaí) e suas regionais, que, durante a realização do Congresso Nacional sobre a questão indígena — São Miguel (RS), 28/04/1978 —, declararam que lutariam contra a falsa emancipação dos índios.

Membros da comunidade acadêmica, especialmente os antropólogos do país reunidos na Universidade de São Paulo (USP), também repudiaram a tentativa de emancipaçáo em nota divulgada no dia 28 de agosto de 1978. Enquanto isso, no dia 6 de julho, participantes do Simpósio de Etnologia "divulgaram documento advertindo que a emancipação dos índios é uma alternativa perigosa ao processo de expropriação territorial que vem sendo enfrentado por essas comunidades" ${ }^{32}$

Durante a realização da XXX Reunião Anual da Sociedade Brasileira para o Progresso da Ciência (SBPC), em São Paulo, houve um debate sobre a questáo indígena no qual o Decreto de Emancipação foi fortemente criticado. Desse debate surgiu um documento -

\footnotetext{
${ }^{28}$ Ibidem, p. 9-10.

${ }^{29}$ Ibidem, p. 11.

${ }^{30}$ Ibidem, p. 12.

${ }^{31}$ Idem.

${ }^{32}$ HISTÓRICO DA EMANCIPAÇÃO. São Paulo. 1979. Comissão Pró-Índio/SP. 1. ed. São Paulo: Ed. Parma Ltda, p. 13. 1979.
} 
Repúdio ao decreto, moção 38, aprovada na Assembleia Geral da XXX Reunião da SBPC, São Paulo - que, entre outras questóes, afirmava:

As populações indígenas brasileiras vem (sic) sendo, há séculos, sistematicamente destruídas e expoliadas (sic) de seus territórios e esse processo vem se intensificando de modo alarmante nos últimos anos. [...] Agora, a elaboração, pelo Ministro do Interior, de um decreto para regulamentar a chamada "emancipação do índio" configura mais uma ameaça para essas populaçôes. [...] Sem a demarcação das terras indígenas é impossível respeitar a diversidade cultural e permitir um processo de interação em bases mais justas entre as sociedades indígenas e a sociedade nacional, que é fundamento de toda emancipação verdadeira. [...] Nós, participantes da XXX Reunião Anual da Sociedade Brasileira para o Progresso da Ciência, denunciando consequências desastrosas que podem advir da promulgação desse decreto, manifestamo-nos contrários a mais essa tentativa de falsa emancipação. ${ }^{33}$

Em Brasília, antropólogos de todo o país se reuniram com representantes da Funai, à época vinculada ao Ministério do Interior (Minter), momento no qual repudiaram e criticaram o projeto do ministro Rangel Reis. Um documento produzido por eles apresentou explicaçôes que justificavam a inviabilidade do decreto. Em princípio, foi ressaltada a condição especial dos índios por viverem sob o regime de tutela e terem o Estado brasileiro como seu tutor. Nesse sentido, ao Estado cabia o dever de protegê-los, uma vez que o próprio os definiu como relativamente capazes no Código Civil de 1916 e na Lei no 6.001 de 1973.

Apesar de o Estatuto do Índio prever o direito desses povos de se libertarem do regime tutelar e ainda anunciar a possibilidade de a emancipação da comunidade indígena ou de seus membros ser feita por decreto do Presidente da República, deve-se considerar que antes de falar em emancipação o governo deveria observar se as responsabilidades do Estado enquanto tutor foram plenamente realizadas. Por exemplo, em 1978 expirava o prazo delimitado pelo próprio Estatuto para que as terras indígenas fossem demarcadas, o que não ocorreu até hoje.

O mais sensato é que estivesse em pauta, naquele ano, a problemática da demarcação das terras indígenas, em vez de o governo tentar se furtar às suas responsabilidades falando em emancipação. "Uma emancipação depende de uma tutela bem-sucedida", ${ }^{34}$ e isso era exatamente o que não ocorria naqueles anos. Para os antropólogos e indigenistas envolvidos, integrar os índios, como pretendia o Governo, à sociedade nacional, naquelas circunstâncias, era o mesmo que "lavar-se as mãos do que lhes venha a acontecer". 35

\footnotetext{
${ }^{33}$ ARQUIVO NACIONAL (Coordenação Regional de Brasília - DF). Dossiê Estudos sobre emancipação indígena. Serviço Nacional de Informação, Divisão de Segurança e Informaçóes do Ministério do Interior. Sigla de Origem: DSI/Minter. 2 out. 1978. Sigilo C. Número do ACE: AO081670. Ano do ACE: 1980. (Fac-símile). ${ }^{34}$ HISTÓRICO DA EMANCIPAÇÃO. São Paulo, op. cit., p. 19.

${ }^{35}$ Ibidem, p. 18.
} 
Outra questão levantada pelos antropólogos no documento, a referida moção 38, chama a atenção para a necessidade de se respeitar a diversidade indígena. Os índios tinham consciência da sua diferença étnica e começavam a demonstrar — as Assembleias de Chefes Indígenas já indicavam esse caminho - discernimento quanto ao fato de que para terem direitos e serem tratados como os demais brasileiros (direitos a igualdade/cidadania) não precisavam deixar de ser eles mesmos (direito à diferença). É como disseram os antropólogos da USP, Unicamp, UnB, UFRJ, Ufpa, entre outras universidades, em documento intitulado "Antropólogos Manifestam-se Contra Projeto de Emancipação de Grupos Indígenas":

Os índios são seres adultos. E são, também, e este é o segundo sentido em que a opinião pública pode se equivocar, respeitáveis em sua diversidade. Eles não têm apenas o direito de serem como nós, mas o de serem eles próprios. Diversidade não significa desigualdade: democracia racial não é, necessariamente, a fusão de todos em um modo de ser único, mas, talvez, o reconhecimento do valor de modos de ser diferentes. ${ }^{36}$

O Estado pretendia, com esse projeto de emancipação, justamente negar essa diferença, ignorando-a ao confundir diversidade com desigualdade e submetendo as populaçóes indígenas do Brasil a uma experiência típica de desrespeito.

O respeito à diversidade é mais do que se aceitar e até admirar aqueles grupos que ostentam uma tradição cultural marcada, com cocares, pinturas e, de preferência, arcos e flechas. Muito mais difícil e igualmente importante, é aceitar esses outros grupos que perderam sua língua e seus costumes tradicionais e que teimam, no entanto, em afirmarem-se índios. Há que se entender que esses movimentos de reconstrução de uma identidade indígena, entre grupos aparentemente semelhantes a qualquer grupo regional, significam a tentativa de recuperar uma imagem dignificante de si mesmos. E, é precisamente por isto, que não existem parâmetros outros para definir uma comunidade ou um de seus membros como índios, senão aqueles justamente adotados pelo Estatuto do Índio, de 1973, em seu artigo 3ํa a saber: índio é quem se identifica e é identificado como tal. ${ }^{37}$

Em parecer sobre a minuta do decreto emitido no dia 10 de julho de 1978, Cardoso de Oliveira discutiu a natureza dessa emancipação desejada pelo Estado. Diante da convicção de que o decreto em análise pretendia conceder "a emancipação civil do índio e/ou da comunidade" e a "doação de terras das reservas" àqueles indígenas e/ou àquelas comunidades que tiverem a sua "maioridade legal" reconhecida, o autor concluiu que apenas um lado da questão estava sendo considerado, a saber: "a perda da identidade indígena e, por conseguinte, a perda do direito à proteção". ${ }^{38}$

\footnotetext{
${ }^{36}$ Idem.

${ }^{37}$ Ibidem, p. 19.

${ }^{38}$ ARQUIVO NACIONAL (Coordenação Regional de Brasília - DF). Dossiê Estudos sobre Emancipação Indigena, op. cit.
} 
Nesse sentido, a emancipação representaria para o indígena a perda do direito à proteção, o que os transformariam em meros grupos/indivíduos proprietários de lotes de terras. Naquele contexto, as terras indígenas estavam, como ainda estão atualmente, ameaçadas, mesmo com a proteção do Estado. Basta lembrar que esses territórios são alvos constantes de invasões e espoliaçóes em pleno século XXI, em decorrência de políticas economicistas representadas por setores muito específicos da sociedade, que as consideram essenciais para o desenvolvimento contínuo do país.

Ainda sobre as consequências diretas da iminente emancipação a qual os indígenas estavam sujeitos em 1978, Cardoso de Oliveira ressaltou as diferenças e os complicadores que há entre a emancipação do indivíduo (o indígena) e a emancipação de uma comunidade como um todo. De sua análise da minuta do decreto, o autor depreendeu que a intençáo do Estado, ao desejar conceder-lhes a "maioridade", era a de dar e assegurar ao indígena ou à sua comunidade o direito de propriedade, sem antes perguntar se eles queriam deixar de ser Kayapó, Xavante, Gavião, Krenak, Mundurucu, Yanomami etc., e, como consequência, se tornarem meros proprietários de lotes. Para Cardoso de Oliveira, nem mesmo os indígenas mais adaptados à vida da comunidade nacional, como os Terena, por exemplo, apresentavam esse desejo; o que buscavam era autonomia para gerir as suas vidas em comunidade: "A experiência etnológica e indigenista tem demonstrado que é autonomia o que mais desejam." ${ }^{9}$

A história demonstra que emancipar os indígenas, como almejava o governo brasileiro naquele ano de 1978, seria um grande erro. Os Estados Unidos da América propuseram e realizaram algo semelhante no final do século XIX — Lei de 1887 ou Lei Dawes — quando determinaram a "divisão das reservas indígenas em pequenos lotes de terra, atribuindo-os individualmente aos índios". O corolário dessa lei foi desastroso para as populaçôes indígenas daquele país. O território indígena norte-americano, em "1934, quando a política de desmembramento foi abandonada, os índios tinham perdido 90 (noventa) dos seus antigos 138 (cento e trinta e oito) milhóes de acres de terras". ${ }^{40}$

A autora da carta da Indian Rights Association, Sandra L. Cadwalader, esclareceu a situação ao general Ismarth nos seguintes termos:

A história norte-americana mostra, sem sombras de dúvida, que, quando a terra indígena está em jogo, as questôes são encobertas por uma nuvem de nobre retórica sobre a necessidade de se civilizar o índio, conceder-lhe cidadania, terminar o "degradante" sistema de reservas [...].

A Indian Rights Association estava entre os grupos reformistas que, na década de 1880, clamavam pela promulgação da Lei Dawes; e é uma posição que possa talvez ser explicada

\footnotetext{
${ }^{39}$ Idem.

${ }^{40}$ CARTA da Indian Rights Association de 26 de outubro de 1978 ao Gal. Ismarth de Araújo Oliveira. Fundação Nacional do Índio/Ministro do interior. Brasília - DF. Brasil. In: HISTÓRICO DA EMANCI$P A C ̧ A \tilde{O}$, op. cit., p. 24. (Traduzida do inglês por Maria-Helena de Barros Pimentel-Advogada.)
} 
no contexto da época, mas a consequente dizimação indiscriminada das terras indígenas não poderá jamais ser justificada. $\mathrm{O}$ povo brasileiro náo pode, com certeza, pretender para os índios brasileiros as mesmas políticas desastrosas que os americanos viram fracassar. A Lei de Emancipação deveria ser cuidadosamente examinada, sem que se detenha na expressão de propósitos grandiosos, pelo terrível preço que pode custar às terras e à cultura indígena. ${ }^{41}$

A respeito do protagonismo eminentemente indígena, eles, os maiores prejudicados caso o Decreto de Emancipação tivesse sido aprovado, também emitiram as suas opinióes e posições. Este foi o principal tema de discussão durante a realização da $12^{a}$ Assembleia de Chefes Indígenas de 1978. De acordo com a fala inicial do padre Thomaz Lisboa, o encontro ocorreu mediante um chamado apressado dos missionários porque o assunto era importante: "Olha, se vocês quiserem vamos reunir todinho vocês (sic), quem puder ir, lá em Goiás Velho, para vocês conversarem assunto muito importante. Vocês já ouviram falar que o governo, da Funai, quer dar um decreto falando de emancipação."²

Dos testemunhos e reinvindicaçóes dessa Assembleia surgiu um documento, "Depoimentos e Exigências da Assembleia de Chefes Indígenas. Goiás, 19 de dezembro de 1978”, no qual o parecer dos indígenas sobre o decreto foi dado. Neste contexto, é importante rememorar que o projeto de emancipação foi sugerido pelo Estado justamente quando este deveria concluir as demarcaçóes das terras indígenas, logo, a emancipação foi apreendida, naquele encontro, como "uma atitude hostil e mal-intencionada contra as comunidades indígenas". ${ }^{43}$ A sequência do texto demonstra que os indígenas tinham consciência de que, se concretizada a emancipação, esta traria danos irreparáveis às comunidades, e, certamente, a destruição de suas bases culturais e identitárias.

No curso do ato público realizado no auditório do Tuca, da PUC/SP, sobre o qual se falará logo mais, os índios Nelson Xangrê e Daniel Pareci também emitiram as suas opinióes sobre o projeto. Para o primeiro, os índios precisavam brigar para garantir os seus direitos, e chamou a atenção para a necessidade de se "respeitar a vivência indígena porque nós temos direito de reclamar nossa vivência que vai complicar com o tempo". ${ }^{4}$

A fala de Daniel Pareci foi mais longa e pontual. Após longos agradecimentos aos presentes e a todos envolvidos na luta contra o Decreto de Emancipação, o índio Pareci declarou que a emancipação almejada pelo governo era um "grave crime contra todos os índios do Brasil”; destacou que não eram mais os selvagens que a televisão e o cinema ainda insistiam em mostrar "para deteriorar e dar uma falsa imagem do índio". 45

Daniel Pareci chamou a atenção para o protagonismo ao ressaltar que a luta indígena seria realizada por eles mesmos, já que, como toda a massa oprimida da sociedade, eles

\footnotetext{
${ }^{41}$ Ibidem, p. 24

${ }^{42}$ Pe. Thomaz Lisboa. In: 12a Assembleia de chefes indígenas. Goiás Velho (Cópia de documento datilografado/Cimi - Setor de Documentação, p. 4, dez. 1978.

${ }^{43}$ HISTÓRICO DA EMANCIPAÇÃO, op. cit., p. 28.

${ }^{44}$ Ibidem, p. 70.

${ }^{45}$ Idem.
} 
também tinham consciência da importância da sua luta como único meio de exigirem que os seus direitos fossem reconhecidos e respeitados. Por fim, especificamente sobre a emancipação, afirmou: "Digo que esta emancipação nada mais, nada menos é que uma arma mortífera que simplesmente nos tirará todo e qualquer direito de reclamar os nossos direitos." ${ }^{\text {"46 }}$

Antropólogos da USP, Unicamp e PUC também se mobilizaram, em conformidade com o presidente do Cimi, e foram unânimes em afirmar que "o decreto de emancipação é uma forma de genocídio"; e a CNBB endossou: "A emancipação será submeter de forma premeditada os povos indígenas às condiçôes de existência que acarretam forçosamente seu extermínio como povo." ${ }^{47}$ No entanto, a atitude mais agressiva da sociedade civil, diante da persistência do ministro Rangel em consumar o seu intento, realizou-se com um ato público que reuniu 2 mil pessoas em São Paulo.

A cena representada por este ato público contra a "Falsa Emancipação das Comunidades Indígenas" é simbólica porque, entre outros aspectos, evidencia o sentido múltiplo próprio de "uma expressão, de dimensôes variáveis" que, "ao significar uma coisa, significa, ao mesmo tempo, uma outra coisa, sem deixar de significar a primeira". ${ }^{48}$ Destarte, a perspectiva hermenêutica se define durante a elaboração do texto, no qual o sentido duplo do simbolismo torna-se evidente pela articulação entre "acontecimentos, personagens, instituiçôes, realidades naturais ou históricas..." ${ }^{\text {49 }}$

O grande acontecimento foi o anúncio do Ministro do Interior Rangel Reis, ainda em fevereiro de 1978, de que o Presidente da República Ernesto Geisel assinaria o Decreto de Emancipação. Várias foram, a partir de então, as vozes de oposiçáo ao decreto ao longo daquele ano. É importante ressaltar que o final da década de 1970 foi marcado pelos chamados anos de abertura política, nos quais o regime autoritário deveria pôr fim à repressão e implantar, lenta e gradualmente, a democracia, ainda que em tese.

Os personagens daquela cena histórica que representou o ato público do dia oito de novembro de 1978 eram inúmeros. No auditório do Tuca, da Pontifícia Universidade Católica de Sáo Paulo, reuniram-se mais de 2 mil pessoas entre antropólogos, representantes de instituiçôes universitárias e religiosas, representantes de comunidades indígenas, estudantes universitários, professores, personalidades políticas, membros de organizaçóes de apoio ao índio etc.

Quando se fez essa grande reuniáo no Tuca, em 78, foi uma coisa fantástica, tinha mais de 2 mil pessoas, eu acho que foi um evento assim realmente em nível nacional. Foi ali que os índios começaram eles mesmos também a aparecer. Tínhamos gente que estava ainda começando na carreira, tinha o Genoíno, tinha o Suplicy, tinha uma porção de pessoas e uma presença muito

\footnotetext{
${ }^{46}$ Ibidem, p. 71.

${ }^{47}$ Ibidem, p. 15.

${ }^{48}$ RICOEUR, Paul. O conflito das interpretaçôes. Ensaios de hermenêutica, op. cit., p. 64.

${ }^{49}$ Idem, p. 65.
} 


\section{Poliene Bicalho}

importante da Igreja, sem dúvida nenhuma, e do Cimi, Dom Thomas Balduíno, etc. A Igreja nos deu muita proteção naquela época. ${ }^{50}$

Uma longa lista de moçóes de apoio foi promovida pela Associação Nacional de Cientistas Sociais, assinada por pessoas e instituiçôes que contribuíram para a realizaçáo do ato, porque comungavam da mesma indignação provocada pelo anúncio do decreto. ${ }^{51}$ A Comissão Pró-Índio de São Paulo surgiu exatamente nesse momento, ${ }^{52}$ como excepcional organização de apoio ao índio, e tornou-se, em razão disso, uma das tantas organizações não governamentais alvos de investigação do Serviço Nacional de Informações (SNI) do regime militar. ${ }^{53}$

As instituiçôes envolvidas eram de variadas origens, destacando-se as universidades e seus respectivos centros acadêmicos estudantis e programas de pós-graduação, a Igreja (católica e evangélica), principalmente o Cimi; e as inúmeras organizaçóes de apoio nacionais e internacionais, como a mencionada Comissão Pró-Índio (CPI/SP e RJ), a Associação Nacional de Apoio ao Índio e suas regionais (Anaís), a Indian Rights Association, entre outras.

A realidade histórica era imensamente favorável à organizaçáo da sociedade civil por meio de seus respectivos movimentos sociais. A oposição ao autoritarismo do regime militar soava como uma sinfonia harmônica aos ouvidos dos setores mais atingidos. "Enquanto os 'chefes indígenas' realizavam os seus primeiros encontros e assembleias, os movimentos sociais urbanos e camponeses, com o apoio das Comunidades Eclesiais de Base, iam às ruas protestar contra o regime."

Uma quantidade enorme de pessoas, moradoras dos maiores centros urbanos, tomou conhecimento de que os indígenas de carne e osso existiam e que eram seres humanos; mais que isso, que lutavam pelo direito de serem respeitados como grupos étnicos diferenciados e cidadãos brasileiros. A impressão relacionada a esses povos começava a mudar — não eram nem tão selvagens nem tão bons, eram apenas pessoas que, como a maioria da população, sofriam com os desmandos da ditadura e com a miséria deste povo brasileiro. ${ }^{55}$

A consciência do direito desses grupos étnicos sofridos e empobrecidos foi o principal sinal de que a ação aparentemente benéfica do governo, com o ato de emancipar o índio, seria

\footnotetext{
${ }^{50}$ VIDAL, Lux. A fundação da Comissão Pró-Índio de São Paulo. Comissão Pró-Índio de São Paulo. Disponível em: <http://www.cpisp.org.br/quem-somos>. Acesso em: 9 jan. 2018.

${ }^{51}$ HISTÓRICO DA EMANCIPAÇÂO, op. cit., p. 31-38.

${ }^{2}$ No dia 20 de outubro de 1978 a Comissáo Pró-Índio de São Paulo foi fundada por vários antropólogos, médicos, linguistas e estudantes de pós-graduação como "uma associação civil de direito privado sem fins lucrativos, suprapartidária, sem distinção de credo ou religião, raça, etnia, classe, orientação sexual e gênero, com sede e foro na cidade de São Paulo, e prazo de duraçáo indeterminado, que se rege pelo presente estatuto e pela legislação em vigor". Art. 1ํㅡㄹ do Estatuto da Comissão Pró-Índio de São Paulo. Disponível em: <http:// www.cpisp.org.br/quem-somos>. Acesso em: 9 jan. 2018.

${ }^{53}$ A Comissão Pró-Índio, Regional do Rio de Janeiro, que também se opôs ao Projeto de Emancipação do Índio - realizando importante ato público no dia 7 de novembro de 1978 no Auditório da ABI, no Rio de Janeiro, que reuniu 700 pessoas - foi alvo de investigação do SNI/Agência Central, conforme Informação no 0991/19/AC/78; SNI/Agência do Rio de Janeiro Informação no 146/119/ARJ/78. Arquivo Nacional (Coordenação Regional de Brasília - DF). Dossiê Comissão Pró-Índio. Sigla de Origem: 19 AC SNI. 13 dez. 1978. Sigilo C. Número do ACE: A001661. Número do Ano do ACE: 1979, p. 1-3. (Fac-símile.)

${ }^{54}$ LACERDA, Rosane Freire. Os povos indigenas e a Constituinte - 1987/1988, op. cit., p. 29.

${ }^{55}$ Analogia ao título da obra $O$ povo brasileiro, de Darcy Ribeiro.
} 
um grande erro do Estado em relação às diversas etnias indígenas do país, que, para além da emancipação, desejavam autonomia, ou seja, buscavam o reconhecimento da sua diferença étnica e o respeito às suas maneiras de se expressar e de viver. Ao se tomar como referência a perspectiva teórica apresentada por Axel Honneth, entende-se que esse momento da luta social indígena desencadeou o "potencial normativo do reconhecimento recíproco" ${ }^{56}$

Segundo Honneth, apenas quando ocorre a diferenciação dos padrôes de reconhecimento, entre a esfera do amor e as do reconhecimento jurídico e da estima social, ${ }^{57}$ é que, nessas duas últimas esferas, evidenciam-se as três formas de reconhecimento recíproco - autoconfiança, autorrespeito e autoestima —, capazes de ampliar "as relaçóes de reconhecimento" ${ }^{58}$ Deste modo, o indivíduo coletivamente organizado, nesse caso, o indígena, passa a "se conceber de modo irrestrito como um ser autônomo e individuado" e a "se identificar com seus objetivos e seus desejos". 59

\section{Por uma hermenêutica da falsa emancipação: a título de considerações finais}

O simbolismo presente na tentativa de emancipação dos índios aparece em diferentes matizes. A princípio, é necessário questionar o que estava por trás dessa iniciativa do governo. De acordo com José de Souza Martins, a ideia da emancipação dos índios surgiu como projeto de um governo ditatorial que pressupunha a existência de indivíduos vivendo em uma sociedade onde existia uma "identidade social básica que deve espelhar o modo de ser e de pensar da classe dominante, da classe que tem o controle do Estado e do seu aparato de repressão". ${ }^{60}$

Nesse sentido, a alteridade do índio soava como subversiva ao regime militar, que, somada a outros complicadores, representava um mal a ser sanado. Com a emancipação, o bondoso Estado daria aos indígenas a cidadania plena, igualando-os aos demais cidadãos. Mas por que emancipá-los naquele momento, exatamente quando eles começavam a se organizar e a

\footnotetext{
${ }^{56}$ HONNETH, Axel. Luta por reconhecimento: a gramática moral dos conflitos sociais. Tradução de Luiz Repa. 1 ed. São Paulo: Editora 34, 2003, p. 266.

${ }^{57}$ Axel Honneth elabora sua base teórica para pensar as relaçóes que desencadeiam os conflitos sociais a partir de três formas de reconhecimento: o amor, o direito e a estima social; e para cada uma dessas formas de reconhecimento o autor definiu uma forma de desrespeito (Esfera do Amor = relações primárias = maus-tratos e violação; Esfera do Direito ou Jurídica = privação de direitos e exclusão $=$ atinge diretamente o indivíduo ou grupo no que tange ao autorrespeito; Estima Social ou Solidariedade = degradação e ofensa = atinge a autoestima dos indivíduos de forma individual ou coletivamente). Quando alguma dessas esferas sofre qualquer tipo de agressão ou desrespeito, principalmente nas esferas do direito e da estima social, que se realizam no âmbito das relaçōes interpessoais, as condições para o conflito entre classes ou grupos específicos tornam-se latentes. Nesse sentido, o direito e a autoestima são determinantes para se compreender o processo de formação e estruturação dos conflitos sociais precursores de movimentos sociais organizados, como o Movimento Indígena no Brasil, por exemplo.

${ }^{58}$ HONNETH, Axel. Luta por reconhecimento: a gramática moral dos conflitos sociais, op. cit., p. 266.

${ }^{59}$ Idem.

${ }^{60}$ MARTINS, José de Souza. A emancipação do índio e a emancipação da terra do índio. In: HISTÓRICO $D A E M A N C I P A C ̧ A \tilde{O}$, op. cit., p. 73.
} 
Poliene Bicalho

lutar por seus direitos? Qual o verdadeiro interesse do Estado ao propor tal projeto? O que ganhariam e o que perderiam os índios com a igualdade jurídica e a cidadania que o Estado abnegadamente lhes ofertava?

Desde o início da década de 1970 os indígenas — como vários outros setores da sociedade civil - começaram a se organizar e a tomar consciência da importância da sua diversidade como fator determinante na luta pelos seus direitos. As Assembleias de Chefes Indígenas foram as primeiras a evidenciar o protagonismo indígena e a capacidade organizacional e reivindicadora desses povos e, em razáo disso, começaram a incomodar o regime militar. Emancipá-los implicaria várias situações favoráveis àquele governo autoritário para o qual urgente era continuar realizando os seus projetos desenvolvimentistas.

A conclusão da demarcação das terras indígenas — esperada para aquele fatídico 1978 — representava um empecilho à realização desses projetos. Assim, a emancipação surgiu como um elo perfeito para o Estado e os seus beneficiados imediatos. Emancipando comunidades inteiras, julgadas pela Funai/Minter quanto ao seu grau de integração, os indígenas deixariam de ser juridicamente índios ${ }^{61}$ e passariam a ser brasileiros de primeira classe, ou seja, deixariam de ser considerados relativamente capazes ${ }^{62}$ e perderiam, assim, o direito à tutela. ${ }^{63}$

Assim, as terras indígenas, propriedades da União, também seriam emancipadas, já que, uma vez transformadas em propriedades, se tornariam meras mercadorias, perdendo o sentido original que a terra tem para o índio.

A ditadura militar dessacralizou a terra indígena, brutalizou o índio. Para este a terra não é coisa, não é mera medida. É a terra dos seus mortos, dos seus mitos de explicação da existência e de justificação das relaçóes sociais... A emancipação da terra indígena é a forma de fazê-la

\footnotetext{
${ }^{61}$ DALLARI, Dalmo de Abreu. O índio, sua capacidade jurídica e suas terras. In: HISTÓRICO DA EMANCIPAÇÃO, op. cit., p. 80.

${ }^{62}$ O Código Civil de 1916 incluiu os indígenas no grupo de pessoas com "incapacidade civil relativa", e, acrescenta, "os silvícolas ficarão sujeitos ao regime tutelar, estabelecido em leis e regulamentos especiais, o qual cessará à medida que se forem adaptando à civilização do País”. Entretanto, a Constituição de 1988 questionou o sentido da tutela e reconheceu aos índios o direito de se organizarem e de conduzirem suas reivindicaçóes de maneira direta, sem a intervenção do Estado, o que, na prática, tem sido conquistado gradualmente. Com o Novo Código Civil — Lei no 10.406 de 10 de janeiro de 2002 —, os índios foram excluídos do grupo dos considerados relativamente incapazes. $\mathrm{O}$ artigo $4^{\circ}$ cita apenas "I — os maiores de dezesseis e menores de dezoito anos; II — os ébrios habituais, os viciados em tóxicos, e os que, por deficiência mental tenham o discernimento reduzido; III — os excepcionais, sem desenvolvimento mental completo; e IV — os pródigos". No parágrafo único do mesmo artigo lê-se: "A capacidade dos índios será regulada por legislação especial." In: Arquivo Nacional (Coordenação Regional de Brasília — DF). Dossiê Regime Tutelar Indígena. Sigla de origem: 17 AC. 16 ago. 1984. Número do ACE: A0452907, p. 2. Brasil. Lei no 10.406, de 12 janeiro de 2002. Novo Código Civil: Exposiçáo de Motivos e Texto Sancionado. Brasília: Senado Federal, Subsecretaria de Ediçôes Técnicas, 2002, p. 65. (Fac-simile)

${ }^{63}$ Art. 9o do Estatuto do Índio (Lei no 6.001): “- Qualquer índio poderá requerer ao Juízo competente a sua liberação do regime tutelar previsto nessa lei, investindo-se da plenitude da capacidade civil, desde que preencha os requisitos seguintes: I — idade mínima 21 anos; II — conhecimento da língua portuguesa; III - habilitação para o exercício de atividade útil, na comunhão nacional; IV — razoável compreensão dos usos e costumes da comunidade nacional." In: CUNHA, Manuela Carneiro da. Os direitos do indio: Ensaios e documentos. São Paulo: Brasiliense, 1987, p. 219.
} 
entrar no circuito da troca, é a forma de torná-la cativa do capital, instrumento de sujeição de quem trabalha. É o capital que está sendo emancipado. ${ }^{64}$

Diante do exposto, pode-se notar que os interesses reais do governo, ao propor tal projeto, não era favorecer os indígenas, mas sim os seus anseios de desenvolvimento econômico a todo custo. $\mathrm{O}$ grande medo que assolou não apenas os indígenas, mas também a sociedade civil organizada, representada pelas entidades de apoio às diversas etnias e demais grupos marginalizados, foi o de que, com a emancipação imposta pelo governo e sem a proteção exercida por este por meio da tutela, os índios engrossassem as fileiras dos setores menos favorecidos da sociedade: caboclos, bugres, posseiros, sem-terra, favelados, miseráveis etc. E as razóes que justificam este temor são muitas, como se demonstrou ao longo do texto.

A resistência indígena e da sociedade civil organizada foi recompensada, após vários gritos de oposição ao decreto, quando "fontes da assessoria de imprensa do Minter, em Brasília, informaram que a Presidência da República decidiu, estrategicamente, esquecer por algum tempo a aprovação do projeto de grupos indígenas". ${ }^{55}$ Esta talvez tenha sido a primeira grande conquista do movimento na era contemporânea do protagonismo indígena.

Entretanto, nem o Estado nem os indígenas desistiram de seus projetos. O primeiro, de maneiras diversas e disfarçadas, continuou tentando extinguir o índio enquanto categoria jurídica. O caso do "Critérios de indianidade" é exemplar, sugeridos em 1980, dos quais a Funai, preconceituosamente, quis se utilizar como "tentava de eliminar índios incômodos". ${ }^{66}$ $\mathrm{E}$ as etnias indígenas brasileiras ainda teriam/têm muita luta pela frente, a fim de garantir os seus direitos e terem a sua diversidade respeitada, porém, sempre e cada dia mais como protagonistas de suas próprias histórias.

\section{Fontes}

ARQUIVO NACIONAL (Coordenação Regional de Brasília — DF). Moção aprovada na Assembleia Geral da 30 $0^{\mathrm{a}}$ Reunião Anual da Sociedade Brasileira para o Progresso da Ciência - SBPC. In: Dossiê Estudos sobre Emancipação Indígena. Serviço Nacional de Informação, Divisão de Segurança e Informaçôes do Ministério do Interior. Sigla de Origem: DSI/Minter. 2 out. 1978. Sigilo C. Número do ACE: AO081670. Ano do ACE: 1980. (Fac-símile)

Parecer do Professor Doutor Roberto Cardoso de Oliveira emitido no dia 10 de julho de 1978. In: Dossiê Estudos sobre a Emancipação Indígena. Serviço Nacional de Informação, Divisão de Segurança e Informações do Ministério do Interior. Sigla de Origem: DSI/Minter. 2 out. 1978. Sigilo C. Número do ACE: AO081670. Ano do ACE: 1980. (Fac-símile)

\footnotetext{
${ }^{64}$ MARTINS, José de Souza. A emancipação do índio e a emancipação da terra do índio, op. cit., p. 75.

${ }^{65}$ HISTÓRICO DA EMANCIPAÇÃO, op. cit., p. 15-16.

${ }^{66}$ CUNHA, Manuela Carneiro da. Critérios de indianidade. Revista Tempo e Presença, Rio de Janeiro, n. 167, p. 4-5, abr. 1981.
} 
. Dossiê Comissão Pró-Índio. Sigla de Origem: 19 AC SNI. 13 dez. 1978. Sigilo C. Número do ACE: A001661. Número do Ano do ACE: 1979. (Fac-símile)

. Dossiê Regime Tutelar Indígena. Sigla de origem: 17 AC. 16 ago. 1984. Número do ACE: A0452907. (Fac-simile)

BRASIL. Lei n ${ }^{\circ}$ 10.406, de 12 jan. de 2002. Novo Código Civil: Exposição de Motivos e Texto Sancionado. Brasília: Senado Federal, Subsecretaria de Ediçóes Técnicas, 2002.

. Constituição (1988). Constituição da República Federativa do Brasil: promulgada em 5 de outubro de 1988, com as alteraçóes adotadas pelas Emendas Constitucionais n. 1/92 a 35/2001 e pelas Emendas Constitucionais de Revisão n. 1 a 6/94. Brasília: Senado Federal, Subsecretaria de Ediçôes Técnicas, 2002.

CARTA da Indian Rights Association de 26 de outubro de 1978 ao Gal. Ismarth de Araújo Oliveira. Fundação Nacional do Índio/Ministro do Interior. Brasília — DF. Brasil. In: HISTÓRICO DA EMANCIPAÇÃO. Comissão Pró-Índio/SP. 1. ed. São Paulo: Parma, 1979. (Traduzida do inglês por Maria-Helena de Barros Pimentel-Advogada).

HISTÓRICO DA EMANCIPAÇÃO. São Paulo. 1979. Comissão Pró-Índio/SP. 1. ed. São Paulo: Parma, 1979, 92 p.

PE. THOMAZ LISBOA. In: $12^{\mathrm{a}}$ Assembleia de chefes indígenas. Goiás Velho, dezembro de 1978. (Documento datilografado.)

\section{Referências bibliográficas}

BARBOSA, Marialva. A narrativa, a experiência e o acontecimento de novos regimes de visibilidade da TV brasileira. Tempo, Rio de Janeiro, v. 9, n. 17, p. 153-172, 2004.

OLIVEIRA, Roberto Cardoso de. Caminhos da identidade: ensaios sobre etnicidade e multiculturalismo. 1. ed. São Paulo: Ed. Unesp; Brasília: Paralelo 15, 2006, 256p.

. A crise do indigenismo. Campinas: Editora Unicamp, 1988, 95p.

CUNHA, Manuela Carneiro da. Critérios de Indianidade. Revista Tempo e Presença, Rio de Janeiro, n. 167, p. 4-5, abr. 1981.

. Os direitos do indio: ensaios e documentos. São Paulo: Brasiliense, 1987, 230p.

DALLARI, Dalmo de Abreu. O índio, sua capacidade jurídica e suas terras. In: HISTÓRICO DA EMANCIPAÇÃO. Comissão Pró-Índio/SP. 1. ed. São Paulo: Parma, 1979, p. 77-82.

FAUSTO, Boris. História do Brasil. 8. ed. São Paulo: Edusp, 2000, 660p.

GOHN, Maria da Glória. Empoderamento e participação da comunidade em políticas sociais. Saúde e Sociedade, São Paulo, v. 13, n. 2, maio/ago, p. 20-31, 2004.

. O protagonismo da sociedade civil: movimentos sociais, ONGs e redes solidárias. 2. ed. São Paulo: Cortez, 2008, 120p. 
(Org.). Movimentos sociais no início do século XXI: antigos e novos atores sociais. Petrópolis: Vozes, 2003, 143p.

GOMES, Mércio Pereira. Os indios e o Brasil. Ensaio sobre um holocausto e sobre uma nova possibilidade de convivência. Petrópolis: Vozes, 1988, 237p.

HONNETH, Axel. Luta por reconhecimento: a gramática moral dos conflitos sociais. Tradução de Luiz Repa. 1. ed. São Paulo: Editora 34, 2003, 296p.

LACERDA, Rosane. Os povos indigenas e a Constituinte - 1987/1988. Brasília: Conselho Indigenista Missionário (Cimi), 2008, 240p.

LAVALLE, Adrián Gurza; CASTELLO, Graziela; BICHIR, Renata Mirandola. Os bastidores da sociedade civil — Protagonismos, redes e afinidades no seio das organizaçóes civis. Centro Brasileiro de Análise e Planejamento. São Paulo: Cebrap, nov. 2006, p. 1-79.

MATOS, Maria Helena Ortolan. Rumos do movimento indígena no Brasil contemporâneo: experiências exemplares no Vale do Javari. 2006. 274f. Tese (Doutorado) — Departamento de Antropologia do Instituto de Filosofia e Ciências Humanas da Universidade de Campinas, Unicamp, São Paulo, 2006.

MARTINS, José de Souza. A emancipação do índio e a emancipação da terra do índio. In: HISTÓRICO DA EMANCIPAÇÃO. Comissão Pró-Índio/SP. 1. ed. São Paulo: Parma, 1979, p. 73-75.

OLIVEIRA, Miguel Darcy de. Sociedade civil e democracia no Brasil: crise e reinvenção da política. In: SORJ, Bernardo; OLIVEIRA, Miguel (Ed.). Sociedade civil e democracia na América Latina: crise e reinvenção da política. São Paulo: Instituto Fernando Henrique Cardoso (IFHC); Rio de Janeiro: Centro Edelstein de Pesquisas Sociais, 2007, p. 73-84.

OLIVEIRA FILHO, João Pacheco de. O nascimento do Brasil e outros ensaios. "Pacificação", regime tutelar e formação de alteridade. Rio de Janeiro: Contra Capa, 2016, 362p.

RIBEIRO, Gustavo Lins. Militares, antropologia, desenvolvimento. In: OLIVEIRA FILHO, João Pacheco (Org.). Projeto Calha Norte. Militares, índios e fronteiras: antropologia e indigenismo, 1. Rio de Janeiro: Peti/Ed. UFRJ, 1990, p. 87-96.

RICOEUR, Paul. O conflito das interpretações. Ensaios de hermenêutica. Tradução de M. F. Sá Correia. Porto: Rés Editora, 1989, 487p.

SECCHI, Darci. Autonomia e protagonismo indígena nas políticas públicas. In: JANUÁRIO, Elias; SELLERI, Fernando Silva; KARIN, Taisir Mahmudo (Org.). Cadernos de Educação Escolar Indigena — Proesi. Barra do Bugres: Ed. Unemat, v. 5, n. 1, p. 11-20, 2007.

TOURAINE, Alain. Palavra e sangue: política e sociedade na América Latina. São Paulo: Unicamp, 1989, 598p.

VIDAL, Lux. A fundação da Comissão Pró-Índio de São Paulo. Comissão Pró-Índio de São Paulo. Disponível em: <http://www.cpisp.org.br/quem-somos>. Acesso em: 9 jan. 2018. 